\title{
Article \\ The Effects of ERM Adoption on European Insurance Firms Performance and Risks
}

\author{
Doureige J. Jurdi *D and Sam M. AlGhnaimat
}

check for updates

Citation: Jurdi, Doureige J., and Sam M. AlGhnaimat. 2021. The Effects of ERM Adoption on European Insurance Firms Performance and Risks. Journal of Risk and Financial Management 14: 554. https:// doi.org/10.3390/jrfm14110554

Academic Editor: David Allen

Received: 9 August 2021

Accepted: 12 November 2021

Published: 16 November 2021

Publisher's Note: MDPI stays neutral with regard to jurisdictional claims in published maps and institutional affiliations.

Copyright: (c) 2021 by the authors. Licensee MDPI, Basel, Switzerland. This article is an open access article distributed under the terms and conditions of the Creative Commons Attribution (CC BY) license (https:// creativecommons.org/licenses/by/ $4.0 /)$.
Department of Economics and Finance, La Trobe Business School, La Trobe University, Melbourne, VIC 3086, Australia; s.al-ghnaimat@latrobe.edu.au

* Correspondence: d.jurdi@latrobe.edu.au

\begin{abstract}
We investigate the effects of adopting enterprise risk management (ERM) on the performance and risks of European publicly listed insurance firms. Using a dataset for 24 years, we report new results which show that ERM adopters realize significant ERM premiums after controlling for other covariates and endogeneity. Several firm characteristics such as size, opacity, and the choice of external monitoring agents such as auditors are significant determinants of adopting ERM. We fill a gap in the literature by assessing the impact of adopting ERM on firm risks and report new findings for our sample, which show that ERM adopters effectively reduce firm total and systematic risks and, to a greater extent, idiosyncratic risk. Firm-level variables such as size, leverage, dividend payments events, and diversification impact firm total risk. Insurers use corporate events such as dividend payments to signal information about reducing risk. Industry and international diversification reduce firm total risk and idiosyncratic risk, respectively.
\end{abstract}

Keywords: enterprise risk management; firm characteristics; firm performance; firm risk; insurance firms

JEL Classification: G20; G22; G30; G32

\section{Introduction}

Enterprise risk management (ERM) provides a holistic approach for identifying, evaluating, managing, and mitigating risks at the enterprise level. The Committee of Sponsoring Organizations of the Treadway Commission (COSO) defined ERM as: "process, effected by an entity's board of directors, management and other personnel, applied in a strategy setting and across the enterprise, designed to identify potential events that may affect the entity, and manage risk to be within its risk appetite, to provide reasonable assurance regarding the achievement of entity objectives" (COSO 2004). Eckles et al. (2014) argue that compliance with the Sarbanes Oxley Act, which aims at enhancing corporate governance, has been a catalyst for firms to build their ERM infrastructure. Nocco and Stulz (2006) claim that ERM creates value for the firm and strengthens its ability to execute its strategic plan. Bohnert et al. (2019) indicate that ERM activities in insurance firms are relevant to implementing Solvency II requirements, especially Pillar 2, and these activities enhance firm value. Hoyt and Liebenberg (2011) find that ERM adoption improves firm value, whereas Beasley et al. (2008) find an insignificant market reaction to appointing a Chief Risk Officer. Anton and Nucu (2020) provide a review of various studies on ERM programs applied in various sectors and document mixed evidence on the effect of ERM adoption on firm performance. Other studies find that ERM reduces the cost of capital (Berry-Stölzle and Xu 2018), stock return volatility (Eckles et al. 2014), and firm solvency levels (Nguyen and Vo 2020).

This study identifies the determinants of ERM in European publicly listed insurance firms and evaluates the effects of ERM adoption on market-based performance and risks of these firms. ${ }^{1}$ We add new empirical evidence to existing findings on the relationship 
between ERM adoption and insurance firm performance using a 24-year long dataset. Existing studies often use short periods, from 1 to 8 years, in the empirical investigation (see Hoyt and Liebenberg 2008; Lechner and Gatzert 2018; Bohnert et al. 2019); an extended dataset is necessary for our analysis, considering that the effects of ERM adoption may require time to be realized in a constantly changing risk environment. In addition, we contribute to the existing literature by assessing the impact of ERM adoption on publicly listed European insurance firms' market-based measures risk and consider firm total risk, systematic risk, and idiosyncratic risk. While it might be reasonable to expect that ERM adoption may reduce the levels of firm risk, implementing adequate risk controls is a consequence of risk assessments and requires time. In addition, the emergence of new risks in the financial services industry and the complexity of the risk management environment pose significant challenges to the effectiveness of ERM programs and their running costs. Furthermore, like banks, insurance firms are subject to moral hazards when they reinsure allowable exposures, which may induce excessive risk-taking. At the same time, one may question whether ERM adoption contributes to risk reduction in the insurance sector, which is highly regulated and often subject to scrutiny by various regulators.

Therefore, we aim to provide new insights to researchers and practitioners by investigating the impacts of ERM adoption on firm risks. Our analysis begins with estimating a logistic regression to identify the determinants of ERM in our sample. Results show that the likelihood of adopting an ERM program is associated with firm size, opacity, and being audited by one of the four global audit firms. We estimate a full maximum likelihood treatment effects model to assess the value premium and identify factors that influence performance. The model addresses the potential of endogeneity bias arising from firm factors that simultaneously affect ERM choice and performance (see Hoyt and Liebenberg 2011). Our results reveal an ERM value premium of $54.3 \%$ and show that firm size and trailing profitability are positively associated with firm performance. Then, we consider the effects of ERM adoption on firm risks since performance improvement in insurance firms might also be a byproduct of minimizing risks. Estimates from a full maximum likelihood treatment effects model show that ERM adoption reduces firm total risk by $28 \%$. Firm size and leverage are positively related to total risk due to the potential of facing higher cash flow volatility and the likelihood of experiencing financial distress, respectively. In addition, we find that firms rely on dividend payment events as a signaling mechanism to convey information about their ability to reduce total risk and achieve a similar effect by reaping benefits from industry diversification. Results also show that European insurance firms in our sample benefit significantly from adopting ERM by reducing systematic and idiosyncratic risks.

The remainder of the paper is organized as follows. Section 2 provides a summary of the relevant literature and the hypotheses development. Section 3 explains the methodology used in the empirical analysis. Section 4 describes the data. Section 5 reports the main results, and Section 6 concludes.

\section{Literature Review and Hypotheses Development}

The literature documents mixed evidence on the value of ERM implementation for firms across various sectors. Using a sample of 120 U.S. companies, from various industries, between the years 1992 and 2003, Beasley et al. (2008) find that the announcement of appointing senior risk executives does not impact firm cumulative abnormal returns in both financial and non-financial firms. However, the market reacts positively to implementing ERM programs as it reduces agency costs and financial distress. Tahir and Razali (2011) conduct a similar study on a sample of 528 Malaysian firms from ten different industries, other than the financial services industry, during 2007 and fail to find a significant relationship between ERM and firm value measured by Tobin's Q. Farrell and Gallagher (2015) analyze the implications of ERM maturity score on firm valuation using data for 225 firms from various industries from 2006 to 2011, most of which operate in the U.S. The authors find that firms with mature ERM implementation have high ERM attribute scores and attract a valua- 
tion premium of around 25\%. Larger firms achieve better ERM attribute scores than smaller firms; for example, for adopting an ERM-based approach, ERM process management, and others. These scores decrease for internationally diversified firms due to difficulties in maintaining ERM practices across different countries. Lechner and Gatzert (2018) identify firm characteristics that impact implementing an ERM system using listed German firms, from various industries, between 2009 and 2013. The authors consider 2013 in their analysis and find that the firm's size is positively related to ERM implementation, whereas financial leverage is negatively related. Firms with international operations and those operating in the banking, insurance, and energy industries impact ERM implementation positively. The authors show that ERM activities increase shareholders' value (as proxied by Tobin's Q) by $41.6 \%$. Using a sample of 162 Spanish-listed firms from various industries, excluding firms from the financial and insurance sectors, from 2012 to 2015, González et al. (2020) conclude that ERM adoption is not associated with changes in performance or reducing the probability of firm bankruptcy. However, the authors find that the appointment of a chief risk officer, although it reduces firm performance, may also improve its financial health.

In the insurance industry, Hoyt and Liebenberg (2008) study the extent to which insurance firms in the U.S. have implemented ERM programs between 2000 and 2005 and evaluate the value of these programs. The authors use a treatment effects model that simultaneously examines ERM determinants and value for 125 firms. They show that ERM programs are positively related to firm size and the pressure from institutional owners and negatively related to leverage and reinsurance. Additionally, they find that ERM adopting firms are valued $16.7 \%$ higher than non-ERM firms after controlling for value determinants and endogeneity bias. Three years later, Hoyt and Liebenberg (2011) conduct a similar study on 117 US insurance firms between the years 1998-2005 to find that, on average, ERM increases firm value by approximately 20\%. McShane et al. (2011) utilize the S\&P ERM insurance rating to study the value relevance of ERM on a sample of 82 insurance companies for which the S\&P has issued an ERM rating. The S\&P ERM insurance rating captures all aspects of the risk management program and reflects its extent of implementation. Using data from 2008, the authors estimate a regression model to investigate the relationship between firm value and the degree to which insurers have implemented ERM. They find a positive relationship between the level of risk management and shareholder value in categories that capture increasing levels of traditional risk management (TRM) but no additional increase in value when shifting from TRM to ERM. ${ }^{2}$ Bohnert et al. (2019) investigate the factors that affect ERM adoption on performance using 42 European insurance firms between 2007 and 2015. Their results show that the firm's size is positively related to ERM implementation, while leverage and return volatility are negatively related to ERM. The authors also find that insurance firms with high-quality risk management ratings have a higher Tobin's Q of $6.5 \%$ than firms with lower risk management ratings.

Given the evidence cited above, we hypothesize that adopting ERM improves firm value and performance. This hypothesis is based on two assumptions; first, we assume that the benefits of adopting ERM exceed costs, and second, adopting ERM would contribute to improving the quality of risk governance (Bohnert et al. 2019) and would not be limited just to a response to regulatory or monitoring agents' pressure. Pagach and Warr (2011) indicate little or no benefit from ERM if adopted purely in response to regulatory pressures.

Nguyen and Vo (2020) investigate the relationship between ERM adoption and solvency for 101 publicly listed insurance firms in the European Union from 2007 to 2013. The authors find that ERM adoption adversely affects firm solvency. They also find that ERM adoption is determined by various factors, including firm size, performance, business type/line, international operations, and demand. Eckles et al. (2014) examine the implications of ERM adoption on U.S. insurance firm risk-taking behavior using data from 1990 to 2008 and report a reduction in the firm's stock return volatility. The authors find that adopting ERM lowers the marginal costs of reducing risks and improves the operating profits per unit of risk. ERM adoption may lead to effective risk governance. Baxter et al. (2013) find, using a sample of banks and insurance companies from 2006 to 2008 selected from 
the S\&P Ratings Direct database, that ERM quality is associated with better governance. The authors argue that market participants react favorably to ERM quality announcements. They also find that higher-risk companies have lower quality ERM.

We view ERM adoption as a progressive step for improving firm risk governance and exploiting natural hedges, and therefore, we hypothesize that ERM adoption reduces insurance firm risks. We focus on market-based risk measures constructed from stock returns or estimated using standard asset pricing models and consider firm total risk, systematic and idiosyncratic risks. We contend that risk reduction could be achieved if the benefits from ERM activities exceed costs. ERM adopters would then exploit natural hedges and eliminate risk duplications, reducing risk management costs while improving performance (Hoyt and Liebenberg 2011). In addition, ERM facilitates risk combinations which would reduce risks if correlations were less than one. Eckles et al. (2014) demonstrate based on results from modern portfolio theory that moving away from a silo-based risk management approach to ERM results in improved loss allocations across firm segments leading to a reduction in risk per dollar spent. In addition, Hann et al. (2013) argue that coinsurance enables diversified firms to transfer resources across business segments to avoid countercyclical deadweight costs; therefore, reducing systematic risk. Berry-Stölzle and Xu (2018) link the adoption of ERM to reducing the cost of capital by reducing a firm's systematic risk. However, reducing systematic risk depends on the extent of coinsurance among diversified business units (Hann et al. 2013). Lastly, we hypothesize that adopting ERM reduces firm idiosyncratic risk. Stulz (1996) and Stulz (2003) argue that risk management activities create value to shareholders in the presence of agency costs and market imperfections. These activities mitigate firm-specific lower tail events. Alternatively, risk management activities could be costly when firms do not face tail risk events, and therefore, these activities may not be value-creating. In addition, if investors can diversify away idiosyncratic risk (Markowitz 1952), then investing in risk management activities may not be desirable.

\section{Methodology}

We begin with estimating a logistic regression to quantify the association between factors likely to affect the decision to adopt or engage in an ERM program and the likelihood of adopting the program.

$$
P(E R M \mid x)=\frac{\exp (x \beta)}{1+\exp (x \beta)}
$$

where $P(E R M)$ is the probability of adopting an ERM program by an insurance firm. The vector of explanatory variables and the constant is denoted by $x$, and $\beta$ is a parameter vector. We use the method of maximum likelihood to estimate the log form specification of Equation (1) where the dependent variable ERM = 1 for firms adopting an ERM program and 0 otherwise. Following the literature, we consider the following determinants of ERM:

Firm size: Hoyt and Liebenberg (2011) and Lechner and Gatzert (2018) show that firm size plays a significant role in determining ERM implementation. Implementing ERM requires substantial resources to acquire the relevant technology, appointing key personnel, and funding related administrative costs, which may discourage small firms with limited resources (Beasley et al. 2005). Allayannis and Weston (2001) report a negative relationship between size and firm value. We define insurance firm size as the natural logarithm of the book value of assets.

Financial leverage: Golshan and Rasid (2012) argue that firms who adopt ERM programs may reduce their debt ratio to lower the probability of financial distress. Conversely, firms with a holistic risk management framework may decide to increase leverage as they would be better positioned to manage risks associated with higher debt levels (Hoyt and Liebenberg 2011; Pagach and Warr 2011). We define financial leverage as the total debt to total assets ratio.

Capital opacity: Pagach and Warr (2011) argue that opaque assets are associated with information asymmetry between the firm and investors, typically resulting in undervaluing the firms' assets. Adopting ERM addresses this problem as it facilitates reflecting the 
firm's risk profile more and its financial strength more accurately to outside stakeholders (Liebenberg and Hoyt 2003). We define capital opacity as the ratio of total intangible assets to the book value of assets.

Financial slack: Pagach and Warr (2011) argue that ERM users are more inclined to increase the level of financial slack to reduce the probability of financial distress. Conversely, ERM users have a lower likelihood of experiencing financial distress due to improved risk management, requiring less liquidity. Several studies report a positive relationship between financial slack and ERM adoption (Pagach and Warr 2011; Berry-Stölzle and Xu 2018). We proxy for financial slack by the ratio of cash and marketable securities to total assets.

Big Three (rating): Lechner and Gatzert (2018) explain that market participants react positively to firms that receive a high credit rating, especially if that rating is from one of the Big Three rating agencies (Standard and Poor's, Moody's, or Fitch). As a result, companies are more likely to implement ERM to signal their commitment to improved management strategies and higher transparency, which ultimately will be positively reflected in their ratings (Hoyt and Liebenberg 2011). We define the big three rating variable as a binary variable that takes a value of 1 if the insurance firm is rated by anyone of the big three rating agencies and zero otherwise.

Big Four (audit): Companies that appoint high-quality auditors are more likely to have better risk management systems because they will be reflected in their published audit reports (Beasley et al. 2005; Lechner and Gatzert 2018). We define big four as a binary variable that takes a value of 1 if the insurance firm is audited by any one of the big four audit firms (Deloitte, PricewaterhouseCoopers, KPMG, and Ernst \& Young) and zero otherwise.

Industrial diversification: Firms operating in more than one segment are less likely to implement ERM due to realizing diversification benefits (Pagach and Warr 2011). However, as the number of business units increases, the complexity and range of risks facing a firm may also increase, leading to an increasing need for a holistic risk management system. Lechner and Gatzert (2018) find that industrial diversification is positively related to ERM. We define industrial diversification as a binary variable that takes a value of 1 if the insurance firm operates in more than one insurance segment and zero otherwise.

International diversification: Internationally diversified firms generally face more risks than domestic firms and must comply with different regulatory requirements across different countries (Hoyt and Liebenberg 2011; Lechner and Gatzert 2018). We define international diversification as a binary variable that takes a value of 1 if the insurance firm has international operations and zero otherwise.

One potential disadvantage of the logistic regression is that it ignores the selectivity bias that occurs when the choice of adopting ERM programs is endogenous. To address a potential endogeneity bias arising from factors jointly affecting the decision to adopt ERM and firm performance, we estimate a full maximum likelihood treatment effects model following Hoyt and Liebenberg (2011).

The treatment effects model estimates the effect of the ERM variable, which is considered as an endogenous binary treatment variable on an observed continuous variable such as performance (or risk) conditional on other determinants of performance.

The model requires estimating a performance regression and selection equations. The performance equation is

$$
y_{i t}=E R M_{i t} \delta+x^{\prime}{ }_{i t} \beta+\varepsilon_{i t}
$$

where $y_{i t}$ denotes a performance or a risk variable, $E R M_{i t}$ is a binary variable that takes a value of 1 if firm $i$ was subject to ERM treatment during year $t$ and zero otherwise. $x^{\prime}{ }_{i t}$ contains a set of explanatory variables. The decision to adopt ERM is modeled as an outcome of an unobserved latent variable $E R M^{*}$, which is a linear function of $\omega^{\prime}{ }_{i t}$, a vector that contains a set of explanatory variables affecting the decision to adopt ERM,

$$
E R M_{i t}^{*}=\omega^{\prime}{ }_{i t} \gamma+\mu_{i t}
$$


where $E R M_{i t}$ is a binary variable equal to 1 if $E R M^{*}>0$; that is if an insurance firm adopts ERM and 0 otherwise. The error terms $\varepsilon_{i t}$ and $\mu_{i t}$ are assumed to follow a bivariate normal distribution with a zero mean vector and covariance matrix $\left[\begin{array}{cc}\sigma_{p} & \rho\end{array}\right]^{\prime}$. Equations (2) and (3) are estimated simultaneously using the method of maximum likelihood.

The primary independent variable of interest is ERM adoption (ERM). We identify whether a firm adopts or implements an ERM program using a method suggested by Hoyt and Liebenberg (2011). This method involves searching for particular words, terms, or phrases that identify risk management practices linked to ERM. ${ }^{3}$ This variable takes a value of zero for all years before the first ERM event recorded and one for the year of the event onwards. We use the variables explained earlier as determinants of ERM.

With respect to performance equation, we use Tobin's $Q$ as a proxy of firm value (Bohnert et al. 2019; Hoyt and Liebenberg 2008, 2011; Lechner and Gatzert 2018; Li et al. 2014; Lin et al. 2012),

$$
\text { Tobin's } Q=\frac{\text { Market value of equity }+ \text { Book value of liabilities }+ \text { Preferred Stock }}{\text { Book Value of Total Assets }}
$$

Tobin's Q indicates that a firm creates (destroys) value by utilizing assets efficiently when it is larger (less) than 1. The ratio is free from management discretion and is a prospective performance measure that reflects future expectations rather than history (Lindenberg and Ross 1981; Hoyt and Liebenberg 2011). To estimate Equation (2), we use the following explanatory variables.

Firm size: McShane and Cox (2009) find that larger life-health insurers enjoy an enhanced value resulting from economies of scale, greater market power, and lower insolvency risk than smaller firms. On the other hand, Allayannis and Weston (2001) explain that large firms may face agency problems that deteriorate firm's value. Hoyt and Liebenberg (2011) and Lechner and Gatzert (2018) report a positive relationship between size and value.

Financial leverage: The relationship between capital structure and firm value is ambiguous in the literature (Lechner and Gatzert 2018). Relying more on debt can increase firm value by reducing the free cash flow that could have been invested in sub-optimal projects by self-interested managers (Hoyt and Liebenberg 2011; Jensen 1986). Furthermore, an increased debt level allows for tax savings (Tahir and Razali 2011). On the other hand, an increased debt level may lead to financial distress, and in some cases, bankruptcy (Hoyt and Liebenberg 2011).

Profitability: Allayannis and Weston (2001) explain that profitable firms tend to be overvalued compared to non-profitable companies. We control for differences in the firms profitability in the sample by adding the return on assets as a control variable in the models used (Hoyt and Liebenberg 2011; McShane et al. 2011).

Revenue growth: Previous studies such as Smith and Watts (1992) and Allayannis and Weston (2001) emphasize the importance of controlling for possible influence from varying investment opportunities in firms. Since firm value is primarily dependent on cash flows from future investments, companies with higher sales are more likely to be able to invest in positive net present value projects, thus enhancing firm value. On the other hand, the uncertainty associated with future growth increases the information asymmetry in the capital market, leading to increasing debt costs, thus negatively impacting value. We define revenue growth as the percentage change in revenues from year to year.

Dividends: Paying dividends may signal to investors that the company has exhausted its growth capabilities, negatively impacting firm value (Allayannis and Weston 2001). Conversely, paying dividends reduces the free cash flow that may have been used for managers' self-interest rather than maximizing value (Hoyt and Liebenberg 2011), typically implying that dividends may also positively impact firm value. Further, paying dividends is sometimes perceived as a signal of strong financial health, which also increases firm value. We define dividends as a binary variable that takes a value of 1 if the insurance firm pays dividends in a financial year and zero otherwise. 
Industrial diversification: A higher level of diversification allows for risk reduction opportunities by realizing interdependencies between various types of risks. Moreover, diversified firms may observe performance enhancement caused by the achievement of economies of scope in addition to greater access to internal capital (Ai et al. 2018). Conversely, diversification increases the complexity of coordination among conglomerates, which may result in the loss of information between them, potential duplication of management activities, and an increase in agency costs (Ai et al. 2018; Hoyt and Liebenberg 2011; Lechner and Gatzert 2018).

International diversification: The same argument for industrial diversification applies equally to international diversification. The benefits from scope economies and the ability to reduce risk will be positively reflected in the firm's value (Hoyt and Liebenberg 2011). Conversely, the decrease in management efficiency and the inability to align the interest of shareholders and insider managers may lead to a reduction in shareholder value instead (Denis et al. 2002).

Besides performance, we estimate the treatment effects model to test whether adopting ERM reduces the risk in insurance firms. We consider three measures of risk as lefthand side variables in Equation (2). These measures are total risk, systematic risk, and idiosyncratic risk (Chen et al. 2006; Pathan 2009). Total risk is calculated as the natural logarithm of the standard deviation of daily stock returns for each fiscal year. Systematic risk is measured by the regression coefficient of insurance firm return on the relevant market index excess return. Idiosyncratic risk is computed annually as the standard deviation of residuals obtained from regressing daily return observations on the Fama-French European three factors.

The determinants of ERM, performance, and risk are summarized in the following functional forms:

$$
\begin{gathered}
E R M_{i t}=\mathrm{f}(\text { Leverage, Opacity, Size Slack, Big Three, Big Four, Ind Div, Int Div })_{i t} \text {, } \\
y_{i t}=\mathrm{f}(E R M, \text { Size, Leverage, ROA, Revenue growth, Dividend, Ind Div, Int Div })_{i t} .
\end{gathered}
$$

\section{Data}

We obtain data for European insurance firms from the Bloomberg and Factiva databases. European insurance firms were identified using the global industry classification system (GICS) provided via the Bloomberg database. The data set is from 1995 to 2018, and it contains 80 firms headquartered in 20 different European countries. ${ }^{4}$

Figure 1 shows that the proportion of ERM engagement increased over time by insurance firms in our sample, reaching $90 \%$ in 2018. We also hand collect data for some variables from audited annual reports and use the Kenneth French data library. Table 1 provides variable definitions and reports the sources of data.

\section{Descriptive Statistics}

Table 2 reports the univariate statistics for the entire sample. ERM years account for $64.1 \%$ of the total firm years available in the data, indicating that most firms in the sample have implemented ERM at some point during the sample period. We test for differences in the mean and median between ERM adopting and non-adopting firms using the $t$-test with unequal variances and the Wilcoxon rank-sum (R.S.) test. These tests show statistically significant differences in Tobin's $Q$, total risk, and idiosyncratic risk between non-ERM adopting and adopting firms $(E R M=0-E R M=1)$ and across most variables used in the analysis. 


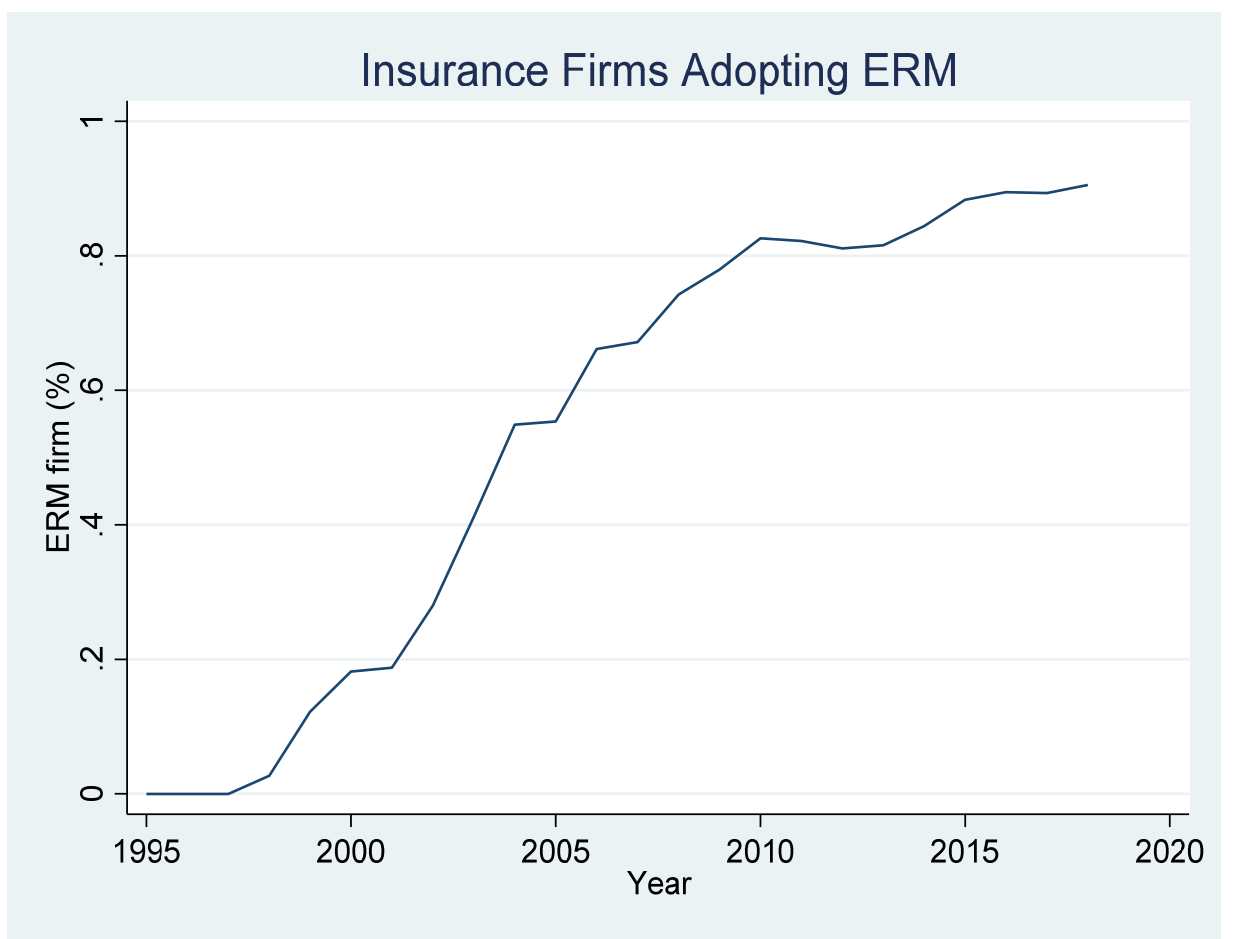

Figure 1. ERM adopting firms.

Table 1. Variable description.

\begin{tabular}{|c|c|c|}
\hline Variable & Definition & Source \\
\hline$E R M$ & $\mathrm{ERM}=1$, Otherwise $=0$ & Annual reports, Bloomberg, and Factiva. \\
\hline Tobin's $Q$ & $\begin{array}{l}\text { (Market Cap + Total Liabilities + Preferred Equity + Minority } \\
\text { Interest)/Total Assets. }\end{array}$ & Bloomberg \\
\hline Total risk & $\begin{array}{l}\text { The annualized standard deviation of the relative price change } \\
\text { for the } 360 \text { most recent trading days closing price. }\end{array}$ & Bloomberg \\
\hline Systematic risk & $\begin{array}{l}\text { Beta is the percent change in the stock price given a } 1 \% \text { change } \\
\text { in the market index. }\end{array}$ & Bloomberg \\
\hline Idiosyncratic risk & $\begin{array}{l}\text { The annual standard deviations of residuals are estimated using } \\
\text { the daily Fama-French European 3-factor model. }\end{array}$ & Kenneth French library \\
\hline Dividends & $1=$ for years the company has paid dividends, $0=$ otherwise. & Bloomberg \\
\hline ERM Leverage & Total Liabilities/Total Assets. & Bloomberg \\
\hline Q Leverage & Total Liabilities/Market Value of Equity. & Bloomberg \\
\hline Opacity & Total Intangible Assets/Total Assets. & Bloomberg \\
\hline Revenue Growth & $\left(\right.$ Revenue $_{t}-$ Revenue $\left._{t-1}\right) /$ Revenue $_{t-1}$ & Bloomberg \\
\hline ROA & Trailing 12 Month Net Income/Book Value of Assets. & Bloomberg \\
\hline Size & Natural Logarithm of Total Assets. & Bloomberg \\
\hline Slack & Cash and Marketable Securities/Total Assets. & Bloomberg \\
\hline Big three (Ratings) & $\begin{array}{l}1=\text { for years the company is rated by one of the big three rating } \\
\text { agencies, } 0=\text { otherwise. }\end{array}$ & Annual Reports \\
\hline Big four (Audit) & $\begin{array}{l}1=\text { for years the company is audited by one of the big four } \\
\text { audit firms, } 0=\text { otherwise. }\end{array}$ & Annual reports and Bloomberg \\
\hline Industry Div. & $1=$ if the firm operates in more than 1 segment, 0 otherwise. & Annual reports and Bloomberg \\
\hline International Div. & $1=$ if firm has international operations, 0 otherwise. & Annual reports and Bloomberg \\
\hline
\end{tabular}


Table 2. Descriptive statistics.

\begin{tabular}{lcccccccc}
\hline Variable & $N$ & Mean & Median & Std. Dev. & Min & Max & $t$-Test & R.S. Test \\
\hline ERM & 1369 & 0.641 & 1.000 & 0.480 & 0.000 & 1.000 & - \\
Tobin's Q & 1369 & 1.182 & 1.030 & 0.504 & 0.685 & 7.665 & $0.154^{* * *}$ & $0.050^{* * *}$ \\
Total risk & 1369 & 0.325 & 0.270 & 0.173 & 0.060 & 1.625 & $0.046^{* * *}$ & $0.050^{* * *}$ \\
Systematic risk & 1366 & 0.008 & 0.010 & 0.128 & -2.769 & 1.832 & -0.002 & 0.000 \\
Idiosyncratic risk & 1369 & 0.938 & 0.780 & 0.590 & 0.096 & 4.024 & $0.305^{* * *}$ & $0.190^{* * *}$ \\
Dividends & 1207 & 0.848 & 1.000 & 0.360 & 0.000 & 1.000 & $-0.111^{* * *}$ & $0.000^{* * *}$ \\
ERM Leverage & 1369 & 0.846 & 0.900 & 0.148 & 0.247 & 0.994 & $-0.068^{* * *}$ & $-0.040^{* * *}$ \\
Q Leverage & 1369 & 13.154 & 7.740 & 20.163 & 0.078 & 147.219 & $-3.207^{* * *}$ & $-3.730^{* * *}$ \\
Opacity & 1369 & 0.035 & 0.010 & 0.070 & 0.000 & 0.584 & $-0.006^{*}$ & $-0.010^{* * *}$ \\
Revenue growth & 1369 & 0.177 & 0.050 & 0.881 & -0.710 & 8.098 & $0.207^{* * *}$ & $0.050^{* * *}$ \\
ROA & 1369 & 0.019 & 0.010 & 0.048 & -0.357 & 0.431 & $0.009^{* * *}$ & $0.000^{* * *}$ \\
Size & 1369 & 9.530 & 10.310 & 2.815 & -0.984 & 13.875 & $-2.700^{* * *}$ & $-2.110^{* * *}$ \\
Slack & 1369 & 0.061 & 0.030 & 0.105 & 0.000 & 0.769 & $0.043^{* * *}$ & 0.000 \\
Big three (Ratings) & 1369 & 0.522 & 1.000 & 0.500 & 0.000 & 1.000 & $-0.314^{* * *}$ & $-1.000^{* * *}$ \\
Bigfour (Audit) & 1369 & 0.888 & 1.000 & 0.316 & 0.000 & 1.000 & $-0.221^{* * *}$ & $0.000^{* * *}$ \\
Industry Div. & 1369 & 0.970 & 1.000 & 0.171 & 0.000 & 1.000 & $-0.017^{*}$ & $0.000^{* *}$ \\
International Div. & 1369 & 0.768 & 1.000 & 0.422 & 0.000 & 1.000 & $-0.264^{* * *}$ & $0.000^{* * *}$ \\
\hline
\end{tabular}

Note: $* * * * * *$ denote the statistical significance at the $1 \%, 5 \%, 10 \%$ levels, respectively.

On average, ERM adopters in our sample have lower Tobin's Q, total risk, and idiosyncratic risk than non-adopters. While differences in the results of these univariate tests are pronounced, these results do not account for other factors that impact performance or risk. Moreover, estimates show that $52.2 \%$ of firms with an ERM program are rated by one of the three biggest rating agencies, and $88.8 \%$ are audited by one of the big four auditing firms. In addition, approximately $97 \%$ of the firms provide insurance products across various industries, and 76.8\% operate internationally across different markets.

Table 3 presents Pearson's correlation matrix for all the variables. Overall, these correlations are weak to moderate. We computed the variance inflation factors for the independent variables and found no evidence of multicollinearity in the data. ${ }^{5}$ Tobin's Q, total risk, and idiosyncratic risk negatively correlate with ERM, whereas the correlation between ERM and systematic risk is positive. The correlation between firm-level variables and ERM shows mixed signs. However, there is a positive correlation between variables that proxy for external monitoring agents and diversification with ERM. These correlations are pairwise, and therefore their signs do not account for the impact of other variables. 
Table 3. Pearson Correlation Coefficients.

\begin{tabular}{|c|c|c|c|c|c|c|c|c|c|c|c|c|c|c|c|c|c|}
\hline & 1 & 2 & 3 & 4 & 5 & 6 & 7 & 8 & 9 & 10 & 11 & 12 & 13 & 14 & 15 & 16 & 17 \\
\hline 1. ERM & 1.000 & & & & & & & & & & & & & & & & \\
\hline 2. Tobin's $Q$ & -0.147 & 1.000 & & & & & & & & & & & & & & & \\
\hline 3. Total risk & -0.129 & -0.078 & 1.000 & & & & & & & & & & & & & & \\
\hline 4. Systematic risk & 0.008 & -0.005 & 0.003 & 1.000 & & & & & & & & & & & & & \\
\hline 5. Idiosyncratic risk & -0.248 & 0.159 & 0.157 & 0.005 & 1.000 & & & & & & & & & & & & \\
\hline 6. Dividends & 0.141 & -0.016 & -0.197 & -0.021 & -0.313 & 1.000 & & & & & & & & & & & \\
\hline 7. ERM Leverage & 0.221 & -0.472 & 0.002 & -0.002 & -0.322 & 0.059 & 1.000 & & & & & & & & & & \\
\hline 8. Q Leverage & 0.076 & -0.176 & 0.152 & -0.083 & -0.005 & -0.090 & 0.376 & 1.000 & & & & & & & & & \\
\hline 10. Revenue growth & -0.113 & 0.033 & 0.167 & 0.004 & 0.135 & -0.082 & -0.145 & -0.020 & 0.030 & 1.000 & & & & & & & \\
\hline 11. $R O A$ & -0.093 & 0.566 & -0.155 & -0.014 & 0.099 & 0.115 & -0.586 & -0.243 & 0.200 & 0.026 & 1.000 & & & & & & \\
\hline 12. Size & 0.460 & -0.421 & -0.176 & 0.005 & -0.496 & 0.253 & 0.568 & 0.163 & -0.215 & -0.137 & -0.261 & 1.000 & & & & & \\
\hline 13. Slack & -0.198 & 0.517 & 0.069 & 0.001 & 0.264 & -0.067 & -0.517 & -0.189 & 0.241 & 0.055 & 0.383 & -0.470 & 1.000 & & & & \\
\hline 14. Big three (Ratings) & 0.302 & -0.216 & -0.079 & -0.029 & -0.162 & 0.184 & 0.243 & 0.162 & -0.050 & -0.080 & -0.140 & 0.524 & -0.188 & 1.000 & & & \\
\hline 15. Big four (Audit) & 0.336 & -0.212 & -0.147 & -0.004 & -0.420 & 0.294 & 0.356 & 0.105 & -0.080 & -0.091 & -0.164 & 0.560 & -0.290 & 0.220 & 1.000 & & \\
\hline 16. Industry Div. & 0.047 & -0.043 & -0.139 & -0.002 & -0.224 & 0.137 & -0.057 & -0.002 & -0.020 & -0.112 & 0.075 & 0.188 & -0.061 & 0.175 & 0.155 & 1.000 & \\
\hline 17. International Div. & 0.300 & -0.256 & -0.093 & 0.030 & -0.441 & 0.303 & 0.325 & 0.065 & -0.023 & -0.115 & -0.175 & 0.476 & -0.341 & 0.276 & 0.336 & 0.066 & 1.000 \\
\hline
\end{tabular}




\section{Main Results}

We begin with estimating a logistic regression to examine the determinants of ERM for insurance firms in our sample and report the results in Table 4. These results show that the coefficient of leverage is statistically significant and negative, indicating that firms adopting ERM reduce their leverage to reduce the likelihood of default.

Table 4. Logistic Regression ERM determinants.

\begin{tabular}{|c|c|}
\hline Variable & $E R M$ \\
\hline ERM Leverage & $\begin{array}{l}-5.636^{* *} \\
(2.527)\end{array}$ \\
\hline Opacity & $\begin{array}{l}12.452^{* * *} \\
(4.284)\end{array}$ \\
\hline Size & $\begin{array}{l}2.308^{* * *} \\
(0.275)\end{array}$ \\
\hline Slack & $\begin{array}{l}-1.478 \\
(3.334)\end{array}$ \\
\hline Big three (Ratings) & $\begin{array}{l}2.646^{* * *} \\
(0.604)\end{array}$ \\
\hline Big four (Audit) & $\begin{array}{l}1.371^{* *} \\
(0.595)\end{array}$ \\
\hline Industry Div. & $\begin{array}{l}-0.302 \\
(1.111)\end{array}$ \\
\hline International Div. & $\begin{array}{l}0.862 \\
(0.920)\end{array}$ \\
\hline Constant & $\begin{array}{l}-19.584^{* * *} \\
(2.979)\end{array}$ \\
\hline Number of Obs. & 1369 \\
\hline Number of Clusters (Firms) & 80 \\
\hline Wald test (Chi-squared) & $126.33^{* * *}$ \\
\hline
\end{tabular}

Firms with more opaque assets are more likely to adopt ERM. Implementing ERM increases the firms' ability to better assess their own risk profile, which may reduce information asymmetry between the firm and its stakeholders. This is likely when firms attempt to improve risk management to reduce the likelihood of financial distress. As expected, larger firms are more likely to engage in ERM. These firms have more resources to adopt an enterprise-wide risk management program to mitigate risks and address continuously evolving directives that regulate the insurance industry and the continuously changing risk environment. Consistent with Hoyt and Liebenberg (2011), firms rated by one of the big three rating agencies are more likely to engage in ERM. The results also show that hiring one of the big four auditing firms positively correlates with ERM. Beasley et al. (2005) explain that firms that employ high-quality auditors are more likely to commit to an integrated risk management framework, provided that it will be reflected in annual reviews. ERM engagement signals the firm's commitment to improving risk management systems to external monitoring agents, which would be reflected positively in their financial review. Lastly, the Wald test indicates that the coefficients are simultaneously different from zero.

Next, we estimate a full maximum likelihood treatment effects model that addresses the endogeneity bias, explained in Section 3. The results are reported in Table 5. The most important result is that ERM adopters are valued 53.4\% higher than non-adopters.

Regarding the control variables, results show a negative relationship between size and performance. Larger insurers have greater bureaucracies and may face more complex agency problems (Lechner and Gatzert 2018), negatively impacting firm value. Consistent with Hoyt and Liebenberg (2011), ROA is positively associated with Tobin's Q. 
Table 5. Full maximum likelihood treatment effects model-Tobin's Q.

\begin{tabular}{|c|c|c|}
\hline Variable & Tobin's $Q$ & $E R M$ \\
\hline ERM & $\begin{array}{l}0.534^{* * *} \\
(0.101)\end{array}$ & \\
\hline Dividends & $\begin{array}{l}-0.014 \\
(0.054)\end{array}$ & \\
\hline ERM Leverage & & $\begin{array}{l}-0.221 \\
(1.036)\end{array}$ \\
\hline$Q$ Leverage & $\begin{array}{l}0.00004 \\
(0.001)\end{array}$ & \\
\hline Opacity & & $\begin{array}{l}3.778^{* * *} \\
(1.185)\end{array}$ \\
\hline Revenue growth & $\begin{array}{l}-0.014 \\
(0.014)\end{array}$ & \\
\hline$R O A$ & $\begin{array}{l}5.768^{* * *} \\
(1.315)\end{array}$ & \\
\hline Size & $\begin{array}{l}-0.084^{* * *} \\
(0.019)\end{array}$ & $\begin{array}{l}0.170^{* * *} \\
(0.049)\end{array}$ \\
\hline Slack & & $\begin{array}{l}0.706 \\
(0.855)\end{array}$ \\
\hline Big three (Ratings) & & $\begin{array}{l}0.209 \\
(0.128)\end{array}$ \\
\hline Big four (Audit) & & $\begin{array}{l}0.850 * * * * \\
(0.288)\end{array}$ \\
\hline Industry Div. & $\begin{array}{l}-0.145 \\
(0.205)\end{array}$ & $\begin{array}{l}-0.406 \\
(0.631)\end{array}$ \\
\hline International Div. & $\begin{array}{l}-0.105 \\
(0.082)\end{array}$ & $\begin{array}{l}0.215 \\
(0.229)\end{array}$ \\
\hline Constant & $\begin{array}{l}1.756^{* * *} \\
(0.243)\end{array}$ & $\begin{array}{l}-1.902 \\
(0.995)\end{array}$ \\
\hline Number of Obs. & 1207 & \\
\hline Number of Clusters (Firms) & 77 & \\
\hline Wald test (Chi-squared) & $58.60 * * *$ & \\
\hline Wald test of indep. equations & $17.23^{* * *}$ & \\
\hline
\end{tabular}

Concerning the ERM equation, the results show that firm size, opacity, and being audited by one of the big four audit firms remain significant determinants of ERM adoption. The Wald test for independent equations rejects the null hypothesis that residuals from Equations (2) and (3) are uncorrelated and support their joint estimation.

Next, we report results using a full maximum likelihood treatment effects model to assess the relationship between adopting ERM and the total risk measure in Table 6.

These results show that ERM engagement is effective in reducing a firm's total risk by $28 \%$. Dividend payment events are negatively associated with total risk. This result is consistent with the risk reduction hypothesis (Grullon et al. 2002; Von Eije et al. 2014; Tripathy et al. 2021), suggesting that firms use these events to convey information to market participants about the reduction in their riskiness. Leverage, however, amplifies total risk. Evidence in the literature indicates that taking on leverage increases the probability of financial distress (Pagach and Warr 2011). In addition, although weakly significant, size is positively associated with total risk. Larger firms engage in complex resource administration and management to enable ERM (Beasley et al. 2005; Nocco and Stulz 2006). These firms face significant uncertainties (Altuntas et al. 2011) and, more importantly, experience volatile cash flows (Pagach and Warr 2011), which in turn will be reflected in stock price volatility. The results also show that insurers benefit from industry diversification. Industry diversification may yield better outcomes from economies of scope, with higher diversification leading to a decrease in operational and financial risks (Pagach and Warr 2011). However, international diversification increases firm total risk, possibly due to a higher 
number and complexity of risks and the need to comply with different national regulatory requirements (Hoyt and Liebenberg 2011). Reeb et al. (1998) argue that firms with foreign sales have higher systematic risk. These firms tend to have higher cash flow volatilities from international activities that are not offset adequately by diversification benefits. The Wald test for independent equations rejects the null hypothesis that the residuals from Equations (2) and (3) are uncorrelated and supports their joint estimation.

Table 6. Full maximum likelihood treatment effects model—Total Risk.

\begin{tabular}{lll}
\hline Variable & Total Risk & ERM \\
\hline ERM & $-0.280^{* * *}$ & \\
Dividends & $(0.033)$ & \\
ERM Leverage & $-0.051^{* *}$ & \\
Q Leverage & $(0.020)$ & -0.782 \\
Opacity & & $(0.554)$ \\
Revenue growth & $0.001^{* * *}$ & \\
ROA & $(0.0004)$ & $2.243^{* *}$ \\
Size & & $(1.090)$ \\
Slack & 0.013 & \\
Big three (Ratings) & $(0.010)$ & \\
Big four (Audit) & -0.224 & $0.184 * * *$ \\
Industry Div. & $(0.200)$ & $(0.045)$ \\
International Div. & $0.009 *$ & -0.794 \\
Constant & $(0.005)$ & $(0.736)$ \\
& & 0.135 \\
Number of Obs. & & $(0.116)$ \\
& & $0.609 * *$ \\
& & $(0.277)$ \\
& & -0.461 \\
& & $(0.359)$ \\
& $(0.057)$ & 0.173 \\
& & $(0.202)$ \\
& & $-1.005 *$ \\
& & $(0.606)$ \\
\hline
\end{tabular}

$\begin{array}{ll}\text { Number of Obs. } & 1207 \\ \text { Number of Clusters (Firms) } & 77 \\ \text { Wald test (Chi-squared) } & 179.19^{* * *} \\ \text { Wald test of indep. equations } & 42.44^{* * *}\end{array}$

Note: ${ }^{* * *}, * * *$ denote statistical significance at the $1 \%, 5 \%, 10 \%$ significance levels; robust standard errors are reported below parameter estimates in parentheses.

We extend the analysis to quantify the effect of ERM adoption on systematic and idiosyncratic risks and report the results in Table 7. The results reported in Panel A show that ERM engagement reduces systematic risk by $16.5 \%$. Similar to the results from Table 6, we find a positive association between size and systematic risk. However, leverage is negatively related to systematic risk. Previous studies have not investigated the relationship between leverage and systematic risk directly; however, Berry-Stölzle and Xu (2018) suggest that ERM adoption reduces a firm's cost of capital, thus decreasing systematic risk.

Results reported in Panel B of Table 7 show that ERM adoption effectively reduces exposure to idiosyncratic risk by $74.3 \%$. Dividend payment events are negatively associated with idiosyncratic risk, which is consistent with the signaling argument discussed above. The results also show that international diversification reduces idiosyncratic risk, which is consistent with rational expectations. Firms may face a higher number of risks and more complex risks (Hoyt and Liebenberg 2011); however, compliance with various national regulations may improve their ability to manage their risk. Opacity and size are significant 
determinants of ERM engagement in the estimates of the treatment effects model for both systematic and idiosyncratic risk, whereas audit appears to be a significant determinant in the latter. The Wald test supports the joint estimation of the risk and ERM equations.

Table 7. Full maximum likelihood treatment effects model—Systematic and idiosyncratic risks.

\begin{tabular}{|c|c|c|c|c|}
\hline \multirow[b]{2}{*}{ Variable } & \multicolumn{2}{|c|}{ Panel A } & \multicolumn{2}{|c|}{ Panel B } \\
\hline & Systematic Risk & $E R M$ & Idiosyncratic Risk & $E R M$ \\
\hline$E R M$ & $\begin{array}{l}-0.165^{* *} \\
(0.069)\end{array}$ & & $\begin{array}{l}-0.743^{* * *} \\
(0.151)\end{array}$ & \\
\hline Dividends & $\begin{array}{l}-0.010 \\
(0.009)\end{array}$ & & $\begin{array}{l}-0.203^{* * *} \\
(0.076)\end{array}$ & \\
\hline ERM Leverage & & $\begin{array}{l}-0.390 \\
(0.560)\end{array}$ & & $\begin{array}{l}0.924 \\
(1.119)\end{array}$ \\
\hline$Q$ Leverage & $\begin{array}{l}-0.0006^{* *} \\
(0.0003)\end{array}$ & & $\begin{array}{l}0.003 \\
(0.002)\end{array}$ & \\
\hline Opacity & & $\begin{array}{l}1.724^{* *} \\
(0.849)\end{array}$ & & $\begin{array}{l}4.384^{* * *} \\
(1.375)\end{array}$ \\
\hline Revenue growth & $\begin{array}{l}0.0004 \\
(0.001)\end{array}$ & & $\begin{array}{l}-0.024 \\
(0.022)\end{array}$ & \\
\hline$R O A$ & $\begin{array}{l}-0.086 \\
(0.073)\end{array}$ & & $\begin{array}{l}-0.230 \\
(1.416)\end{array}$ & \\
\hline Size & $\begin{array}{l}0.010 \text { ** } \\
(0.005)\end{array}$ & $\begin{array}{l}0.149 * * * \\
(0.038)\end{array}$ & $\begin{array}{l}-0.016 \\
(0.022)\end{array}$ & $\begin{array}{l}0.128^{* * *} \\
(0.045)\end{array}$ \\
\hline Slack & & $\begin{array}{l}-0.602 \\
(0.670)\end{array}$ & & $\begin{array}{l}-1.091 \\
(0.760)\end{array}$ \\
\hline Big three (Ratings) & & $\begin{array}{l}0.225 \\
(0.146)\end{array}$ & & $\begin{array}{l}-0.061 \\
(0.170)\end{array}$ \\
\hline Big four (Audit) & & $\begin{array}{l}0.362 \\
(0.243)\end{array}$ & & $\begin{array}{l}1.006^{* * *} \\
(0.260)\end{array}$ \\
\hline Industry Div. & $\begin{array}{l}-0.011 \\
(0.029)\end{array}$ & $\begin{array}{l}-0.419 \\
(0.384)\end{array}$ & $\begin{array}{l}-0.385 \\
(0.323)\end{array}$ & $\begin{array}{l}-0.405 \\
(0.337)\end{array}$ \\
\hline International Div. & $\begin{array}{l}0.030 \\
(0.018)\end{array}$ & $\begin{array}{l}0.191 \\
(0.212)\end{array}$ & $\begin{array}{l}-0.241^{* *} \\
(0.122)\end{array}$ & $\begin{array}{l}0.207 \\
(0.242)\end{array}$ \\
\hline Constant & $\begin{array}{l}0.030 \\
(0.030)\end{array}$ & $\begin{array}{l}-0.849 \\
(0.607)\end{array}$ & $\begin{array}{l}2.289^{* * *} \\
(0.402)\end{array}$ & $\begin{array}{l}-2.304^{* *} \\
(1.021)\end{array}$ \\
\hline Number of Obs. & 1207 & & 1207 & \\
\hline Number of Clusters (Firms) & 77 & & 77 & \\
\hline Wald test (Chi-squared) & 12.15 & & $60.77 * * *$ & \\
\hline Wald test of indep. equations & $4.95 * *$ & & $28.72 * * *$ & \\
\hline
\end{tabular}

Note: $* * * * *, *$ denote statistical significance at the $1 \%, 5 \%, 10 \%$ significance levels; robust standard errors are reported below parameter estimates in parentheses.

Overall, we find that ERM adoption leads to value creation for insurance firms in our sample, which is realized by improved performance and reduced risks as indicated by the market-based variables used in our analysis.

\section{Conclusions}

This paper examines the impact of adopting ERM on European publicly listed insurance firms' performance and risks using a 24-year long dataset. We identify firms that adopt ERM using a text search method proposed by Hoyt and Liebenberg (2011). Using logistic regression, we find that the determinants of ERM adoption in our sample include firm financial variables such as leverage, opacity, and size and variables that identify leading monitoring agents who provide credit ratings and auditing services.

Our assessment of the impact of ERM adoption on firm performance and risks relies on using the full maximum likelihood treatment effects model, which addresses the endogeneity bias arising from variables affecting ERM adoption and performance (or risks) simultaneously. We summarize our contributions as follows: First, we report a new result that identifies, for our sample, a significant value premium for ERM adopters. 
Second, we show that adopting ERM reduces firm total risk significantly. This result holds for systematic and idiosyncratic risks. These findings are new, and they complement existing results in relevant ERM studies that have considered other risks such as default risk, earnings volatility, and solvency (Altuntas et al. 2011; Berry-Stölzle and Xu 2018; Pagach and Warr 2011; Nguyen and Vo 2020).

The reported effects of ERM adoption by publicly listed insurance firms in our sample have important implications for policymakers and regulators concerned about the financial health and stability of the insurance industry. Adopting ERM programs by insurance firms provides another corporate governance mechanism that improves firm value and reduces risks. Our findings lead us to recommend the adoption of effective ERM programs which may facilitate the application of Solvency 2 standards and, in particular, selected provisions set for Pillar 2, which focus in part on risk governance and setting up processes that enable the firm's own risk and solvency assessment (OSRA). In addition, ERM adoption may add value to the role of monitoring agents, and this appeals to investors in insurance firms as our results have shown that these firms have realized, on average, significant value premiums and reduced risks (total risk, systematic, and idiosyncratic risks).

We note, however, that we have only considered publicly listed insurance firms due to data limitations. Several firms operating in the insurance industry in Europe are not listed on stock exchanges. For example, Nguyen and Vo (2020) indicate that many insurance firms in France are mutual corporations that are not publicly listed. Hence, considering non-listed insurance firms together with listed firms provides a more comprehensive assessment for the insurance industry and forms the basis of a potential extension for this paper.

Author Contributions: Conceptualization, D.J.J.; methodology, D.J.J.; software, D.J.J. and S.M.A.; validation, D.J.J.; formal analysis, D.J.J.; investigation, D.J.J.; data curation, S.M.A.; writing—original draft preparation, D.J.J. and S.M.A.; writing—review and editing, D.J.J.; supervision, D.J.J.; project administration, D.J.J. All authors have read and agreed to the published version of the manuscript.

Funding: This research has not received funding.

Institutional Review Board Statement: Not applicable.

Informed Consent Statement: Not applicable.

Data Availability Statement: The dataset was obtained from subscription databases identified in the Data Section of the paper.

Conflicts of Interest: The authors declare no conflict of interest.

\section{Notes}

1 The dataset covers a long period (1995-2018) relative to other studies. During this period several directives and regulations have been issued across European countries and have impacted risk management systems in European insurance firms. Pradier and Chneiweiss (2017) document various directives and regulations that have impacted the evolution of the insurance industry in Europe since the 1970s. More recently, the European Parliament and the Council agreed that the Solvency II Directive (including the amendments introduced by Omnibus II) should apply as of 1 January 2016.

2 McShane et al. (2011) discuss the differences between TRM and ERM. The former is silo-based and uncoordinated focusing mainly on financial risk, whereas the latter is broader and includes operational and strategic risks besides financial risks.

3 The terms we search for include: 'chief risk officer', 'risk management director', 'enterprise risk management', 'holistic risk management', 'strategic risk management', 'risk committee', 'risk' and various other synonyms including: 'enterprise-wide risk management', 'integrated risk management', 'firm-wide risk management', 'group risk management', 'comprehensive risk management', 'risk coordinator', 'risk manager', 'COSO', 'ORSA' and 'integrated framework' and other.

4 Insurance firms in this sample are headquartered in Austria, Belgium, Cyprus, Denmark, Finland, France, Germany, the United Kingdom, Greece, Iceland, Ireland, Isle of Man, Italy, Luxembourg, Malta, Netherlands, Norway, Spain, Sweden, and Switzerland. Firms are included in the dataset if they have four years or more of data.

5 Estimates of the variance inflation factor for independent variables are lower than 10. 


\section{References}

Ai, Jing, Vickie Bajtelsmit, and Tianyang Wang. 2018. The Combined Effect of Enterprise Risk Management and Diversification on Property and Casualty Insurer Performance. The Journal of Risk and Insurance 85: 513-43. [CrossRef]

Allayannis, George, and James P. Weston. 2001. The Use of Foreign Currency Derivatives and Firm Market Value. The Review of Financial Studies 14: 243-76. [CrossRef]

Altuntas, Muhammed, Thomas R. Berry-Stoelzle, and Robert E. Hoyt. 2011. Implementation of Enterprise Risk Management: Evidence from the German Property-Liability Insurance Industry. The Geneva Papers on Risk and Insurance. Issues and Practice 36: 414-39. [CrossRef]

Anton, Sorin Gabriel, and Anca Elena Afloarei Nucu. 2020. Enterprise Risk Management: A Literature Review and Agenda for Future Research. Journal of Risk and Financial Management 13: 281. [CrossRef]

Baxter, Ryan, Jean C. Bedard, Rani Hoitash, and Ari Yezegel. 2013. Enterprise Risk Management Program Quality: Determinants, Value Relevance, and the Financial Crisis. Contemporary Accounting Research 30: 1264-95. [CrossRef]

Beasley, Mark S., Richard Clune, and Dana R. Hermanson. 2005. Enterprise Risk Management: An Empirical Analysis of Factors Associated with the Extent of Implementation. Journal of Accounting and Public Policy 24: 521-31. [CrossRef]

Beasley, Mark, Don Pagach, and Richard Warr. 2008. Information Conveyed in Hiring Announcements of Senior Executives Overseeing Enterprise-Wide Risk Management Processes. Journal of Accounting, Auditing E Finance 23: 311-32. [CrossRef]

Berry-Stölzle, Thomas R., and Jianren Xu. 2018. Enterprise Risk Management and the Cost of Capital. The Journal of Risk and Insurance 85: 159-201. [CrossRef]

Bohnert, Alexander, Nadine Gatzert, Robert E. Hoyt, and Philipp Lechner. 2019. The Drivers and Value of Enterprise Risk Management: Evidence from Erm Ratings. The European Journal of Finance 25: 234-55. [CrossRef]

Chen, Carl R., Thomas L. Steiner, and Ann Marie Whyte. 2006. Does Stock Option-Based Executive Compensation Induce Risk-Taking? An Analysis of the Banking Industry. Journal of Banking E Finance 30: 915-45. [CrossRef]

COSO (Committee of Sponsoring Organizations of the Treadway Commission). 2004. Enterprise Risk Management-Integrated Framework. Available online: www.coso.org (accessed on 1 August 2021).

Denis, David J., Diane K. Denis, and Keven Yost. 2002. Global Diversification, Industrial Diversification, and Firm Value. The Journal of Finance (New York) 57: 1951-79. [CrossRef]

Eckles, David L., Robert E. Hoyt, and Steve M. Miller. 2014. The Impact of Enterprise Risk Management on the Marginal Cost of Reducing Risk: Evidence from the Insurance Industry. Journal of Banking E Finance 43: 247-61. [CrossRef]

Farrell, Mark, and Ronan Gallagher. 2015. The Valuation Implications of Enterprise Risk Management Maturity. Journal of Risk and Insurance 82: 625-57. [CrossRef]

Golshan, Nargess, and Siti Zaleha Abdul Rasid. 2012. Determinants of Enterprise Risk Management Adoption: An Empirical Analysis of Malaysian Public Listed Firms. World Academy of Science, Engineering and Technology, International Journal of Social, Behavioral, Educational, Economic, Business and Industrial Engineering 6: 242-49.

González, Luís Otero, Pablo Durán Santomil, and Aracely Tamayo Herrera. 2020. The Effect of Enterprise Risk Management on the Risk and the Performance of Spanish Listed Companies. European Research on Management and Business Economics 26: 111-20. Available online: https://www.sciencedirect.com/science/article/pii/S2444883420303028 (accessed on 1 September 2020).

Grullon, Gustavo, Roni Michaely, and Bhaskaran Swaminathan. 2002. Are Dividend Changes a Sign of Firm Maturity? The Journal of Business (Chicago, Ill.) 75: 387-424. [CrossRef]

Hann, Rebecca N., Maria Ogneva, and Oguzhan Ozbas. 2013. Corporate Diversification and the Cost of Capital. The Journal of Finance 68: 1961-99. [CrossRef]

Hoyt, Robert E., and Andre P. Liebenberg. 2008. The Value of Enterprise Risk Management: Evidence from U.S. Insurance Industry. Available online: https://www.soa.org/globalassets/assets/files/resources/essays-monographs/2008-erm-symposium/mono2008-m-as08-1-hoyt-abstract.pdf (accessed on 5 March 2021).

Hoyt, Robert E., and Andre P. Liebenberg. 2011. The Value of Enterprise Risk Management. Journal of Risk and Insurance 78: 795-822. [CrossRef]

Jensen, Michael C. 1986. Agency Costs of Free Cash Flow, Corporate Finance, and Takeovers. The American Economic Review 76: 323-29.

Lechner, Philipp, and Nadine Gatzert. 2018. Determinants and Value of Enterprise Risk Management: Empirical Evidence from Germany. The European Journal of Finance 24: 867-87. [CrossRef]

Li, Qiuying, Yue Wu, Udechukwu Ojiako, Alasdair Marshall, and Maxwell Chipulu. 2014. Enterprise Risk Management and Firm Value within China's Insurance Industry. Acta Commercii 14: e1-e10. [CrossRef]

Liebenberg, André P., and Robert E. Hoyt. 2003. The Determinants of Enterprise Risk Management: Evidence from the Appointment of Chief Risk Officers. Risk Management and Insurance Review 6: 37-52. [CrossRef]

Lin, Yijia, Min-Ming Wen, and Jifeng Yu. 2012. Enterprise Risk Management: Strategic Antecedents, Risk Integration, and Performance. North American Actuarial Journal 16: 1-28. [CrossRef]

Lindenberg, Eric B., and Stephen A. Ross. 1981. Tobin's Q Ratio and Industrial Organization. The Journal of Business (Chicago, Ill.) 54: 1-32. [CrossRef]

Markowitz, Harry. 1952. Portfolio Selection. Journal of Finance 7: 77-91. [CrossRef]

McShane, Michael K., and Larry A. Cox. 2009. Issuance Decisions and Strategic Focus: The Case of Long-Term Care Insurance. The Journal of Risk and Insurance 76: 87-108. [CrossRef] 
McShane, Michael K., Anil Nair, and Elzotbek Rustambekov. 2011. Does Enterprise Risk Management Increase Firm Value? Journal of Accounting, Auditing \& Finance 26: 641-58. [CrossRef]

Nguyen, Duc Khuong, and Dinh-Tri Vo. 2020. Enterprise Risk Management and Solvency: The Case of the Listed Eu Insurers. Journal of Business Research 113: 360-69. [CrossRef]

Nocco, Brian W., and René M. Stulz. 2006. Enterprise Risk Management: Theory and Practice. Journal of Applied Corporate Finance 18: 8-20. [CrossRef]

Pagach, Donald, and Richard Warr. 2011. The Characteristics of Firms That Hire Chief Risk Officers. The Journal of Risk and Insurance 78: 185-211. [CrossRef]

Pathan, Shams. 2009. Strong Boards, Ceo Power and Bank Risk-Taking. Journal of Banking E Finance 33: 1340-50. [CrossRef]

Pradier, Pierre-Charles, and Arnaud Chneiweiss. 2017. The Evolution of Insurance Regulation in the Eu since 2005. In Financial Regulation in the Eu: From Resilience to Growth. Edited by Raphaël Douady, Clément Goulet and Pierre-Charles Pradier. Cham: Springer International Publishing, pp. 199-251.

Reeb, David M., Chuck C. Y. Kwok, and Hyungkee Young Baek. 1998. Systematic Risk of the Multinational Corporation. Journal of International Business Studies 29: 263-79. [CrossRef]

Smith, Clifford W., and Ross L. Watts. 1992. The Investment Opportunity Set and Corporate Financing, Dividend, and Compensation Policies. Journal of Financial Economics 32: 263-92. [CrossRef]

Stulz, René M. 2003. Rethinking Risk Management. The Revolution in Corporate Finance, 4th ed. Hoboken: Blackwell Publishing, pp. 367-84.

Stulz, René M. 1996. Rethinking Risk Management. Journal of Applied Corporate Finance 9: 8-25. [CrossRef]

Tahir, Izah Mohd, and Ahmad Rizal Razali. 2011. The Relationship between Enterprise Risk Management and Firm Value: Evidence from Malaysian Public Listed Companies. International Journal of Economics and Management Sciences 1: 32-41.

Tripathy, Niranjan, Da Wu, and Yi Zheng. 2021. Dividends and Financial Health: Evidence from U.S. Bank Holding Companies. Journal of Corporate Finance 66: 101808. [CrossRef]

Von Eije, Henk, Abhinav Goyal, and Cal B. Muckley. 2014. Does the Information Content of Payout Initiations and Omissions Influence Firm Risks? Journal of Econometrics 183: 222-29. [CrossRef] 